\title{
Flexicurity in a life-course perspective
}

\author{
Ute Klammer*
}

\section{Summary}

This article extends the analysis of flexicurity to take account of the life-course perspective; in the international flexicurity debate such an approach has so far not been systematically taken. The article focuses on the question of what options will be needed for time allocation in different phases of life and over the whole life of an individual, and what financial resources could be combined to finance those phases. The first section discusses methodological and conceptual issues related to flexicurity and the life course. In the second section, longitudinal data from Germany is presented to illustrate some of the relevant patterns of, and changes within, life courses. The third and main section deals with policy implications. Four crucial objectives of a flexicurity policy based on a life-course approach are identified, and a range of options to improve flexibility and security over the lifetime are discussed. These options include measures to increase time sovereignty, subsidised part-time schemes for care and lifelong learning, the use of accumulated pension savings to finance other activities during the course of working life, and the role of minimum provision in social security schemes.

\section{$\nLeftarrow \nLeftarrow$}

\section{Sommaire}

Cet article élargit l'analyse de la flexicurité pour tenir compte de la perspective du cycle de vie; dans les débats sur la flexicurité au niveau international, une telle approche n'a jusqu'ici pas été systématiquement adoptée. Dans cet article, l'auteur se penche sur la question de savoir quelles options seront nécessaires pour l'allocation du temps dans les différentes phases de la vie et au cours de toute la vie d'un individu, et quelles ressources financières pourraient être combinées pour financer ces phases. La première partie examine les questions méthodologiques et conceptuelles liées à la flexicurité et au cycle de vie. La deuxième partie présente des données longitudinales provenant d'Allemagne en vue d'illustrer certains modèles pertinents de cycles de vie, ainsi que les changements qui s'y produisent. La troisième et principale partie de l'article traite des conséquences sur le plan politique. L'article identifie quatre objectifsclé de politique en matière de flexicurité basée sur une approche du cycle de vie et analyse une série d'options visant à améliorer la flexibilité et la sécurité tout au long de la vie. Ces options incluent des mesures pour augmenter la maîtrise de la souveraineté du temps, les systèmes de travail à temps partiel subventionnés pour faire face aux responsabilités familiales et l'apprentissage tout au long de la vie, l'utilisation de l'épargne accumulée pour financer d'autres activités pendant le cours de la vie active, et le rôle des dispositions minimales dans les systèmes de sécurité sociale.

\section{$\$ *$}

* Senior researcher, Institute of Economic and Social Research (WSI/Hans-Böckler-Foundation), Düsseldorf.

E-mail: ute-klammer@boeckler.de 


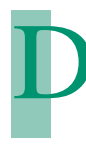

\section{Zusammenfassung}

In diesem Beitrag wird die Analyse der Flexicurity um die Perspektive des Lebensverlaufs erweitert. In der internationalen Debatte zum Thema Flexicurity ist ein derartiger Ansatz bislang nicht systematisch angewandt worden. Die Autorin befasst sich mit der Frage, welche Optionen für die Zeitverwendung in den verschiedenen Lebensphasen und über das gesamte Leben des Einzelnen hinweg erforderlich sein werden, und welche finanziellen Ressourcen miteinander kombiniert werden könnten, um diese Phasen zu finanzieren. Im ersten Teil werden methodische und konzeptuelle Fragen im Zusammenhang mit Flexicurity und dem Lebensverlauf erörtert. Im zweiten Teil werden Längsschnittdaten aus Deutschland vorgestellt, um einige relevante Muster von und Veränderungen in Lebensläufen zu veranschaulichen. Der dritte Teil des Beitrags befasst sich mit den Voraussetzungen für politische Maßnahmen in diesem Bereich. Die Autorin nennt vier wesentliche Ziele einer Flexicurity-Politik, die von einer Lebenszyklusperspektive ausgeht, und erörtert eine Reihe von Optionen zur Verbesserung des Verhältnisses von Flexibilität und Sicherheit aus der Perspektive des Lebensverlaufs. Zu diesen Optionen gehören Maßnahmen zur Erhöhung der Zeitsouveränität, subventionierte Programme zur Vereinbarkeit von Teilzeitarbeit mit Betreuungspflichten und lebenslangem Lernen, die Verwendung von angespartem Rentenkapital für die Finanzierung anderer Aktivitäten während des Arbeitslebens und die Rolle von Mindestschutzbestimmungen in den Sozialversicherungssystemen.

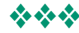 \\ Why and how the flexicurity debate should be linked to the life-course perspective: some methodological and conceptual issues}

One of the key future challenges of the world of work and life, and of the accompanying labour market and social policy measures, will be to integrate flexibility and security. This challenge has come to the fore in the debate over 'flexicurity' - initially in the 1990s in the Netherlands and Denmark, and more recently also in other European countries. The general consensus is that the goal of 'flexicurity' is to create a new balance between flexibility and security so as to provide an alternative to a deregulation-only policy - as well as an alternative to current rigidities in the areas of labour law and social policy. There is still no standard international definition of 'flexicurity'. In the Netherlands, for example, the prevailing opinion is that policies should only be described as 'flexicurity policies' if they simultaneously increase both flexibility as well as the (social) security of those affected (e.g. Wilthagen 2001 and in this issue, implicitly also in the 1999 'Law on Flexibility and Security'). In Denmark, the debate about 'flexicurity' focuses primarily on mobility in the labour market (see Braun 2002; Madsen 2003 and in this issue); a typical characteristic is the combination of a particularly low level of dismissal protection with high unemployment benefits (with replacement rates of up to $90 \%)$.

In the German debate, the concept of 'flexicurity' is used in a broader sense to cover first, a wider range of issues considered to fall within the scope of flexibilisation, and 
secondly, the discussion of methods and actors by which this flexibilisation could be secured (Klammer and Tillmann 2002). As far as employees are concerned, key questions relate to new professional risks that are still only inadequately covered by the social insurance system, including risks that result from the self-exploitation of so-called 'entreployees' (Voß and Pongratz 1998) ${ }^{1}$. But flexibility is also increasingly shaping private living models. Flexicurity therefore also touches upon the time and support needs of different groups of employees in connection with their work-life balance. Only by looking at the interplay between flexibility in the realm of employment and flexibility in the private sphere is it possible to arrive at an adequate assessment of the former and to ensure that it is accompanied by adequate security.

Meanwhile, the idea that we have to reconcile flexibility with security has reached the official publications of the European Commission. Although the publications usually do not (yet) employ the term itself, the idea behind flexicurity - looking for new balances between flexibility and security - reappears frequently. In the European Union's Employment Guidelines for 2003 the balance between flexibility and security is seen as a crucial goal:

'Providing the right balance between flexibility and security will help support the competitiveness of firms, increase quality and productivity at work and facilitate the adaptation of firms and workers to economic change' (Council of the European Union 2003, paragraph 12).

Accordingly, the European Commission's new report Employment in Europe 2003 contains a chapter on 'Flexibility, security and quality in work' (European Commission 2003, ch. 4).

Some aspects in the Commission's more recent publications hint at a perspective that has so far played only a minor role within the flexicurity debate: the life-course perspective. Picking up on such concepts as lifelong learning and active ageing, the 2003 Employment Guidelines state: 'this requires developing comprehensive national strategies based on a life cycle approach' (Council of the European Union 2003, paragraph 15).

The life-course perspective is not new; it has played an important role in debates on labour market and social security issues since the 1960s. It has recently been a subject of renewed interest in the context of demographic change, changing lifetime work patterns of individuals and the discussions on a new organisation of time over working life (see e.g. European Foundation 2003). The goal of this paper therefore is to link the flexicurity debate to the life-course perspective. This implies that the focus is widened and narrowed at the same time. It is widened insofar as it focuses on the dynamic, long-term effects of flexibility and security. Only when the dynamic dimension of time is included

1 'Entreployee' is the term used to describe a new type of employee who markets his or her working abilities on his/her own initiative and who, although formally a dependent employee, bears the risks that have traditionally been entrepreneurial risks. 
in the analysis does the impact of flexibility and discontinuity become obvious (e.g. an accumulation of job changes, working time changes and/or periods out of employment). The focus is narrowed insofar as it concentrates on the employee's/individual's development over time and on social security systems, and especially on the question of how these systems have to be reorganised better to meet the life-course perspective. This focus implies that the employers' perspective is not systematically addressed, although it is assumed that a reorganisation of 'security' along the life course is a precondition for the employability of the workforce and therefore employers will profit from it.

\section{Changing work biographies - empirical results for Germany and beyond}

An in-depth analysis of changing work biographies can only be based on longitudinal panel data. Unfortunately there is only limited European comparative data of this kind. Therefore the following section of the paper will be illustrated by data for Germany, in particular on the results of a research project on flexicurity for which longitudinal data was evaluated (Klammer and Tillmann 2002). Some results are connected to the specific German situation, but many trends are also reported in other European countries.

Data analysis for Germany clearly reveals that work biographies have changed considerably from cohort to cohort and that changes are ongoing:

- As far as flexible or 'atypical' work contracts are concerned many of these work forms have not grown in number as fast as reported from some other European countries. Exceptions have been the growth of regular part-time and small part-time jobs. However, the relatively slow growth of flexible work relationships on the aggregate level masks the fact that the trend towards more flexible, unstable forms of work has mainly affected a) the cohorts newly entering the labour market and b) low-qualified groups of the workforce. Today in west Germany the youngest groups of employees are on limited employment contracts about six times as often as employees in the near-retirement age groups. The concentration of 'atypical' contracts within certain parts of the workforce can become a problem, if such contracts are not restricted to a short period in working life (e.g. the entrance period), because certain kinds of atypical employment (e.g. marginal part-time jobs) do not give access to full employment and social security protection.

- In most cases, atypical and flexible work is involuntary and is only accepted due to a lack of choice on the labour market. This is not the case for part-time work, in particular among women, who choose part-time work 'voluntarily' in most cases to reconcile work with family responsibilities. It can be debated whether this can really be termed 'voluntary' part-time work, given the institutional framework which is not suited to combining full-time work with family responsibilities. Yet it can be stated that regular part-time work in Germany is as stable as full-time work and does not imply being affected by the higher risks associated with other aspects of atypical work. 
- Analysis of the cumulative data from the German Socioeconomic Panel for the period since the mid-1980s fails to confirm the general assumption that there has been a noticeable increase in the number of individual status transitions (e.g. between different employment forms and relationships as well as between labour market, education system, private household or retirement). Recent studies have confirmed that job tenure has been surprisingly stable in Germany (and several other Western countries) over the past years (Erlinghagen and Knuth 2002). However, some exceptions concerning the developments of transitions should be noted (Klammer and Tillmann 2002). A remarkable increase occurred in the number of transitions from work to unemployment, a weaker increase in the opposite direction (see also Gautié 2003 for France).

- The overall majority of job changes (about two-thirds) - as well as changes of profession - are still voluntary. However, younger employees and those with a low level of qualifications and atypical work contracts have to change jobs involuntarily with particular frequency and 'move up' less frequently than all employees on average when they do so. This hints at the fact that problematic discontinuities might increase in the work biographies of younger and low qualified workers.

Longitudinal analysis of the development of work biographies reveals significant changes (datasource 'AVID' for cohorts born in 1936-1955, including projections for the younger cohorts up to their legal retirement age). In the longitudinal view, the expansion of some forms of 'atypical' work or unemployment becomes much more visible than in a cross-sectional analysis.

As far as the total number of working years is concerned, there is a certain trend towards convergence between men and women: whereas the average number of years for men is decreasing, it is increasing for women. However, even among the youngest cohorts investigated (born in 1951-1955) there remains a 'gap' of more than seven years of employment for women as compared to men, according to the AVID-projections.

Depending on the cohort, between $16 \%$ and almost $20 \%$ of German men and between $8 \%$ and $13 \%$ of German women will have had a period of self-employment during their working life.

Almost four out of five German women born in 1951-55 will have at least one year of 'regular' part-time work during their working career and one-third will have worked for at least one year in a marginal part-time job ${ }^{2}$.

There will be a considerable decrease in the length of periods women spend at home, but even in the 'youngest' cohort (born in 1951-55) two-thirds of all women will still have work interruptions of more than one year to care for children.

2 At the time when the AVID-data was released a 'marginal part-time job' meant no more than 360 $\mathrm{DM} /$ month and 15 hours/week. New regulations introduced in 2003 abolished the time threshold and increased the income level for these jobs, now named 'mini-jobs', to $€ 400$. This has already led to a considerable further increase of these marginal jobs with low social protection. 
According to longitudinal analysis for all west German cohorts born in 1931-1965 (database: IAB-Beschäftigtenstichprobe) unemployment is increasingly part and parcel of an individual's employment history. Of persons born during the years 1941-45 onwards, in each subsequent cohort the share of workers affected by unemployment grew, and they were already being affected at a younger age. Whereas among the working population born in 1941-45 only $8 \%$ of all men and $4 \%$ of all women experienced (registered) unemployment before the age of 30 , this increased to $53 \%$ for both sexes in the cohort born in 1961-65.

Longitudinal analysis (AVID data) of the development of earnings over the lifetime reveals that from cohort to cohort there is a trend among men to earn a greater share of their lifetime income in later years (e.g. due to prolonged education) and in fewer years (e.g. due to early retirement). That implies that every single year of work becomes more important to one's lifetime income, and interruptions during this period can become more problematic. Analysis of the life course also brings out the still enormous differences between men and women concerning income from work. West German women born in 1936-1955 only receive 43\% of men's average lifetime income from work. The loss of lifetime earnings increases with each child a woman has. Among west Germans born in 1936-55, women with one, two or three children earn over their lifetime only $58 \%, 43 \%$ or $30 \%$ respectively of a childless woman's wage, and even less compared to men. Women with periods of part-time work are more 'successful' after their family phase compared to women in general and accumulate more working years than women on average. Clearly, part-time work has been more successful than career interruptions in providing a link to the labour market (see also Schwarze 2002; more sceptical results are reported in Beblo and Wolf 2002).

\section{Implications for social policy - elements of a concept of flexicurity in a life-course perspective}

What are the shortcomings of social security as far as these changes in work biographies are concerned? What are the challenges that in particular arise from the new risks to which younger cohorts and the low qualified are increasingly exposed, such as shorter and more discontinuous working biographies, unemployment and involuntary transitions?

As far as social security is concerned, the challenge to be met can be described as finding a new equilibrium between 'commodification' and 'decommodification', to use the terminology of Esping-Andersen (1990).

Commodification in this sense means that help for (re-) integration into the labour market has to be offered. This can include assistance at the beginning of one's working life, after periods out of the labour market or after periods of reduced or precarious labour market participation, but also support for mobility (e.g. regional mobility, job mobility). 
The topic of commodification has been pushed a lot by the shift towards an 'active welfare state'. But, in spite of the general trend towards activation, countries differ widely in the degree and targeting of the help offered, as well as in the level of coercion they employ (Lødemel and Trickey 2001).

Decommodification means independence from the labour market through the right to leave the labour market in certain situations and life phases, and in particular through financial support for these phases. This has not been made superfluous by the shift towards the active welfare state. On the contrary: there is a need to rethink and redefine under which circumstances and for which phases people are not expected to gain a living through work, and how these periods (before, during and after the 'potentially active' phase) can be covered.

Empowering people with regard to flexibility includes protection against non-acceptable flexibility as well as for desired flexibility. Among the questions to be tackled from the life-course perspective are the following:

- How can continuity in working life be supported and involuntary discontinuities be avoided?

- How can desired flexibility and discontinuity be enabled?

- How can transitions be supported?

- How can cash benefits and other forms of financial support be reallocated?

The following considerations will be oriented towards these four fields of action.

\section{Support for continuity and upward mobility}

Whether 'atypical' employment relationships or interruptions to employment prove to be precarious for the people concerned depends, among other things, on their cumulative duration and development over the individual's life course. One key task of labour law and social security systems is to give support for continuous employment and upward mobility. This refers in particular to the long-term prospects of people with unstable jobs. Action in this field requires some more knowledge about long-term risks of 'atypical' jobs (e.g. fixed-term contracts, agency work and hiring-out of employees, 'mini-jobs') and interruptions of the work biography. Specific health risks, unemployment risks or income risks that might occur in the long run have to be identified. Fixedterm contracts, for example, not only contain a higher risk of future unemployment than regular jobs, but might also lead to increased stress due to the feeling of insecurity (Pearce 1998; De Witte et al. 2002). For the life course, not only actual events or discontinuities play a role, but also the respective expectations and fears. According to OECD data, the subjective feeling of job insecurity increased in seven European countries between the mid-1980s and the mid-1990s; this trend was most significant in Great Britain, Germany and the Netherlands (OECD 1997: 129-160; Walker et al. 2000: 2031). High subjective job insecurity can influence people's professional performance but can also lead them to refrain from decisions such as marriage or family formation. 
A sustainable concept of flexible work therefore requires some effort to prevent occupational diseases and stress by limiting job insecurity. High benefits in cash and kind in the event of job loss might help employees to accept the risk of becoming unemployed, as the Danish example shows ${ }^{3}$. Employment contracts with temporary work agencies that guarantee a certain continuity of work and remuneration without guaranteeing employment in a specific company are one way of combining flexibility and security over time. When regulating flexible jobs through labour law, emphasis has to be put on the pathways from more flexible to less flexible jobs to make sure that flexible work is not a dead-end option. Within the Dutch approach towards flexicurity, this is one of the key areas of regulation, e.g. in the so-called 'Flex-Wet' introduced in 1999. This law gave workers with flexible jobs (such as on-call work or temporary work) more legal security and defined the path towards more stable employment. This development has been enforced by a collective agreement for 1999-2003 in the sector of temporary agency work by which agency workers gradually acquire more rights in line with the ongoing duration of their employment relationship (Wilthagen 2001: 18, and in this issue).

In terms of social security one of the main problems of flexible jobs and discontinuous working biographies is that these may be accompanied by an equally discontinuous coverage by social insurance (Klammer 2000). The challenge therefore is to give people in non-standard jobs access to social security systems. At the company level, the most effective way of supporting continuity in times of economic crisis and decreasing demand for labour is by replacing external forms of flexibilisation (in other words, the laying-off of employees) with internal forms of flexibilisation - such as adjustment of working times as well as further training of employees to equip them to meet new content-based requirements. In Germany, new regulations on working time accounts and 'opening clauses' in collective agreements have greatly extended the freedom of action of companies in this field, and these options are increasingly being used. Employees contribute to this strategy of flexibilisation by accepting (temporary) cuts in income in exchange for employment stability. They can secure their human capital, which is an advantage for the employer, too, and can therefore lead to a win-win scenario. In addition, this strategy keeps down expenses of the unemployment insurance compared to lay-offs. One incentive would be to reward companies for substituting dismissals by internal adjustments. This could be done, for example, through tax relief or by making transfers from unemployment insurance funds. In this context, it also has to be ascertained whether and how the legal options to employ a 'flexible' workforce and the costs of dismissals should be differentiated according to the size of the company, because smaller firms have only restricted options to adjust to changing circumstances and changing labour demand by means of internal labour markets ${ }^{4}$.

The focus of social security on providing security for different life phases should comprise an 'empowerment' element geared towards helping employed people to maintain

3 Interestingly, the subjective feeling of job insecurity is higher in Germany (in spite of the quite rigid employment protection legislation) than in Denmark (OECD 1997; Walker et al. 2000).

4 In Germany recent labour law reforms have stressed this differentiation, e.g. in the field of protection against dismissals. 
(or regain) their employability. The development of concepts for lifelong learning plays a key role in this area. This approach is currently considered to be of central importance within the framework of the European Employment Strategy (see e.g. the European Commission's 'Memorandum of Lifelong Learning' from 2000). Lifelong learning is directly linked to the life-course perspective. Training and lifelong learning appear to be crucial given the specific problems faced by the low qualified on the flexible labour market. At present, the low qualified workforce as well as older workers - both problem groups of the labour market - are strongly underrepresented in training measures. Across the EU, only $2.7 \%$ of low qualified workers of prime age participated in training in 2001, whereas the figure was $15.5 \%$ among the highly qualified of prime age. Among older workers, it was $1.8 \%$ of the low qualified and $9.7 \%$ of the highly qualified (European Commission 2003: 173). Differences between countries are considerable, however. In Denmark, for example, participation by older workers in training measures is nine times as high as in Germany (Braun 2002: 671). Employers will only offer training to low qualified or older employees if they can expect a positive return on their investment. The foreseeable trend to delay the age at which older workers can withdraw from the labour force could raise incentives for employers to invest in lifelong learning since it will extend the time span of the pay-off period (European Commission 2003: 174).

The employee, the employer and the state can all profit from lifelong learning, since it is a prerequisite for continuous employment. The employer profits because training employees according to the company's demands can reduce costs for illness among incapable and stressed employees, as well as costs for early retirement, dismissals or the hiring of new staff. The employee profits because training increases their adaptability (functional flexibility) both within the company and between companies in the external labour market. The state and the social insurance system profit when unemployment can be avoided. Therefore all the above-mentioned actors should be involved in the financing of training activities. Companies can offer learning time accounts as a flexible instrument for employees to save time for training throughout their employment history (Keller and Seifert 2002). However, empirical evidence shows that employers tend to focus training on their core staff; collective agreements also show a bias towards insiders (Wilthagen 2001: 17). Although the European Commission in its concept of lifelong learning stresses the role of social partners in regulating offers for training, the flexible workforce and groups with high labour market risks will also need additional offers for training. The state could offer state-funded entitlements for target groups with special labour market risks, e.g. tax-financed training vouchers (Wilthagen 2001: 17). Another option to involve the employee and the social security system would be to change the unemployment insurance into an 'employment insurance' (Rabe and Schmid 1999, 2000) or 'employability insurance', reserving one part of one's social security contributions for a personal training account that can be used to finance stages of qualification. In the Netherlands, the government has promoted the idea of using existing workers' savings schemes to finance further education and training, or personal development accounts for those who do not have adequate financial resources of their own (Stuurgroep Verkenning Levensloop 2002; European Foundation 2003: 131). 


\section{Support for discontinuity}

A second important task for labour law and social security is to support flexibility and discontinuity over the lifetime where it is needed. Employees have different time needs in different phases of their life. This has become more obvious during recent years when women have increasingly entered the labour market but the question of social care (for children, or the frail elderly) has remained in part to be solved privately.

An acceptable 'adult worker model' would have to allow variations and fluctuations in working times for people in different life situations and with different priorities. The job of the state is to generate the legal framework for different time-based options and to decide which of these options are to be financially supported by means of social welfare policy. This includes legal rights to adjust one's working time (working time reduction/working time extension) as well as options to leave and to re-enter the labour market (e.g. for parental leave). All European countries have some legal options to adjust working time or to leave temporarily the labour market (at least for maternity leave); however, a systematic approach to working time adjustments over the lifetime is still missing.

Some of the German reforms of recent years - such as the 'Law on Part-Time Employment and Fixed-Term Contracts' and the 'The Law on Child-Raising Allowance and Parental Leave' (both adopted in 2001) have been steps in this direction.

In an employment-oriented society, there is also an increasing need for work release entitlements for people who have to care temporarily for adult relatives in need of care. Rights of this kind already exist in some countries, e.g. in Belgium, Sweden or the Netherlands (Plantenga and Koopmans 2002: 164).

At the same time the German provisions on parental leave (that are 'generous' in an international comparison in time-based terms) clearly show the limits to the influence of the legislator: the right of mothers (parents) to take advantage of parental leave and to employment security during this phase is regularly undermined in practice in cases where those affected are in fixed-term employment - something that is increasingly common among younger employees in particular (see section 2). Other time-based options (such as access to sabbaticals) are also often confined in practice to the core workers who are on unlimited employment contracts.

It has to be taken into account that companies are becoming increasingly important as complementary actors on the 'work and care stage'. Due to the direct interrelationship between company working hours and the day-to-day arrangements of families, this is the main area in which company-level measures can help to improve the reconciliation of work and family life. Companies implement the framework defined by the state and by collective agreements and they draw up provisions to operate within this framework. A recent (2003) survey of works councils conducted by the WSI shows that, in the overwhelming majority of companies, employees have options to adapt working hours to suit the requirements of family life (within the limits set by the company) $)^{5}$. Currently, in

5 A company survey conducted by the Hertie Foundation (Hertie Stiftung 2003) arrives at the same conclusion. 
about $90 \%$ of German companies, there is some kind of option for the flexibilisation of working time to suit family demands. The option of taking time off in lieu to compensate for overtime previously worked exists in three out of four companies and is the most frequently cited means of adapting working time to the needs of the family. Other options that play a role are flexi-time, whereby the employee can flexibly choose when to start and end the working day, part-time work, or coming to some kind of arrangement with superiors or other team members.

An important field for flexibility is the area of working time accounts (WTAs). Many German companies have introduced WTAs since the mid-1990s, mainly for economic reasons. Working time accounts currently exist in $29 \%$ of companies employing $40 \%$ of the workforce (Bauer et al. 2003: 183). WTAs that create options for the location and distribution of working time can be used in various ways to meet time needs of employees. But employees can only use flexible working times to suit their requirements if they enjoy wide-ranging access rights to their saved-up working time credits. The existence of a flexible working time model per se tells us nothing about whether it helps to meet the employee's interests. The specific provisions relating to these working time accounts are the decisive factor.

From the point of view of employees with care responsibilities, concepts for working times in companies must cater to several requirements. Working times should be predictable and reliable; there should be flexibility to address family-related needs (e.g. via autonomous withdrawals from working time accounts); there should be options in the area of working time duration (e.g. switching between full-time and part-time and viceversa as well as different working hours for part-time employees); there should be the option to obtain time-out phases for the busy periods in an individual's life; overtime that does not create some kind of 'time credit' should be avoided, and weekend or evening work should be minimised (as these are the most important communal times for parents and children, see Klenner et al. 2003).

The most important regulatory instrument for working times in Germany is the sectoral collective agreement, although company-level arrangements are playing an everincreasing role. Company-level agreements need to be negotiated in the companies to ensure that decentralisation does not automatically translate into deregulation. Only in very few cases are the existing collectively agreed provisions explicitly geared towards the reconciliation of work and family life. This is an area in which the collective bargaining parties and the players at company level still need to make up lost ground.

It appears, however, that the 'working culture' within the company is more important than specific company-level provisions (for the US see Hochschild 2002). Ultimately, the necessary social policy debate on role models should lead to a paradigm shift in companies, creating a situation in which each employee is automatically also seen as a person with time needs beyond paid work (e.g. as a care-giver or as somebody involved in other socially relevant activities). This means that companies should no longer base their planning concepts on the assumed norm of the employee - particularly the qualified employee - who is freed from the full range of household duties. 
The more smoothly the concepts for working time adjustments operate, the lower the potential for disruptions to company routines and the lower the risks of additional costs being incurred (e.g. due to the absence of parents from the workplace). The state can require or encourage companies to adopt a more family-friendly policy by introducing statutory provisions and creating incentives of various kinds - such as tax benefits for companies which provide certain family-friendly services, by making the awarding of public contracts dependent on family-friendly corporate policies, or through certification schemes and public awards. The collective bargaining parties - the employers' federations and the trade unions - and the negotiating parties at company level - the employers and the works councils - can agree on options pointing in this direction. This will pave the way for better integration of employment and care. Since 2001 when the amended Works Constitution Act came into force, German works councils have been responsible for promoting the reconciliation of work and family life. Following this regulation, this topic has been the subject of discussion in a large number of companies during the last two years.

Economic arguments may create a greater incentive to ensure that personnel policy in companies is more family-friendly. A cost-benefit analysis of the economic effects of family-friendly measures in ten German companies showed an average return on investment of $+25 \%$. The study also showed that family-friendly policies avoid over $50 \%$ of the costs incurred as a result of the lack of reconciliation of work and family (in particular bridging, fluctuation and reintegration costs; see Prognos 2003).

What remains unresolved is the question of how companies can be motivated to implement family-friendly working time policies not only in times when qualified employees are scarce or for core employees who they want to keep but also for employees with lower-level qualifications who are easier to replace.

\section{Support for transitions}

Both in cases of involuntary discontinuities (e.g. in the case of unemployment) and in cases of voluntary discontinuities (e.g. in the case of sabbaticals or parental leave) transitions from status to status occur. An important field for a policy oriented towards flexicurity is to support these transitions and to limit the negative effects of transitions in the field of social security. An urgent task, for example, is to improve the portability of occupational pension claims in the event of job changes. To date, long minimum waiting times for occupational pensions often disadvantage employees who change jobs. When pension claims cannot be transferred, this limits labour market flexibility and employees' mobility. An example of good practice in this field is the German pension reform of 2001 whereby the portability of occupational pension claims has been increased considerably.

In particular, support may be necessary for re-entry into the labour market. Help for transitions requires an extended access to active labour market policies for certain groups, but also to cash benefits to help during transitions. The combination of empowerment strategies and monetary security provisions also paves the way for individuals voluntarily to take on - and master - the accompanying risks (such as the decision to 
become self-employed). Transitions and patchwork biographies require an extension of the coverage of social insurance systems, since new groups of workers with atypical jobs or career breaks in particular suffer from exclusion from the systems and insufficient social security rights.

The transition (back) to work has for years now been at the core of Western welfare state reforms and the reorientation towards the 'active welfare state'. In spite of the common terminology there are still huge differences as far as the methods, the targeting and the degree of activation are concerned. What also differs considerably is the degree of coercion employed. In their European comparison, Van Berkel and Hornemann Møller (2002: 54) identify at least four different philosophies behind activation, ranging from strictly paternalistic approaches to approaches that stress the autonomy of the individual. Many evaluation studies (e.g. on the British 'New Deal' programmes) unfortunately do not provide much information on the long-term consequences of activation. On the aggregate level, however, overall economic development seems to remain one of the decisive factors for the 'success' of labour market integration through activation (Cebulla 2002).

Within the 'transitional labour market approach' many elements and structures that could serve as bridges between one status and another and could therefore help to master transitions have been identified and analysed (see e.g. Rabe and Schmid 1999; Schmid 2000; Schmid and Gazier 2002). Instruments that have proven their worth in practice in Germany are so-called 'transfer companies' that prepare employees threatened by dismissals for a new job and subsidies that help people to become selfemployed. Some new instruments to help people during transitional periods like the 'personnel service agencies' or the 'Ich- $A G$ ', a state-subsidised self-employment scheme, still need to stand the test of time. What is required is to develop further the transitional labour market approach in a normative way. It is necessary to clarify what transitions should be covered and to rank the instruments according to their importance. In a lifecourse perspective, priority should be given to those transitions and transitional labour markets that help to prevent the long-term marginalisation of specific groups at risk.

From a life-course perspective, a very important future task will be to re-organise and to support both the first entry and the final exit of people from the labour market. It has to be acknowledged that both transitions have changed their character. They are no longer transitions in the strict sense but have developed into complete phases of their own (Gautié 2003). The entrance phase is usually characterised by unstable jobs and short spells of unemployment and frequently lasts for several years until the first permanent job is attained. The exit phase might also consist of a phase of unemployment, a partial or phased retirement scheme, early exit as a result of inability, etc.

Looking at the average concentration of the active phase into fewer and fewer years in life (see section 2 above) an important goal would be to reverse the trend towards a later entry into the labour market, in particular by better organising and condensing education at school and university and by avoiding early gaps between phases of education 
or between education and the first job. This applies in particular to some of the 'conservative' and the 'Mediterranean' welfare states within the European Union.

The retirement age should become more flexible to enable people to decide on their final exit from the labour market according to their own preferences and financial means. Some countries (e.g. Italy, Sweden) have reformed their pension systems in this direction during the past years. To enable people to stay in the workforce longer according to the European Union's 'Stockholm' and 'Barcelona targets' (that aim at increasing the employment rate for older workers as well as the average retirement age), real options for partial retirement that take the physical and mental exhaustion of many older workers into account have to be developed. Financial incentives for employers who hire the older unemployed could also help to meet the Stockholm and Barcelona targets. A 'decompression' of working life would not only help to regain financial sustainability within the public pension systems but would also help to redistribute the income risk over the full life course.

\section{Reallocation of financial support}

Providing reliable options in different life phases in order to modify working time is an important element for combining flexibility and security. However, this must be complemented by provisions for the monetary cushioning of voluntary and involuntary discontinuities in areas where such assistance is necessary. These can be called 'integrated options' (European Foundation 2003: 127ff.).

One set of options to cover phases of insufficient income from work (e.g. due to parttime work or sabbaticals) is oriented towards new intertemporal redistribution of financial means. The idea is to give individuals more freedom and options about how to distribute their prospective lifetime income over their own life, taking into account different needs in different phases of life. Some ideas in this field of action have recently been developed and promoted in the Netherlands. In 2002, a Dutch government commission proposed to use sources from supplementary retirement schemes to finance options for paid leave at an earlier phase of the life course (Stuurgroep Verkenning Levensloop 2002; European Foundation 2003: 131). Giving people the option to use some of their expected retirement income earlier in life, e.g. to cover financial needs in the 'rush hour of life' (when children have to be brought up and time and money are scarce) could also lead to a longer participation of older workers in the labour market. Similar ideas are being developed within the European Commission (Jacobs 2002).

However it can be questioned whether younger cohorts - different to many of today's older people - would still be able to accumulate such a 'reserve' for old age that they could use up in advance without risking poverty in their old age. New options to redistribute one's lifetime income over the life cycle would give the individual more freedom, but ignore the fact that different groups of people have different needs across their life course. Whereas some people do a lot of care work, for example (bringing up children, caring for elderly), others are never involved in this kind of work. The question is 
whether these activities are to be regarded as a private responsibility or as socially useful tasks that should be supported collectively. In the first case, options to redistribute time and money over one's lifetime would be an adequate, 'privatised' solution. In the latter case, new questions of interpersonal redistribution over the lifetime arise.

Due to the common concern about demographic development, in recent years the notion that care work has to be supported by society has gained ground in many European countries. This would call for a 'care time model' which partly compensates the loss of income from work for parents or other care-givers. Such integrated options for workers with care obligations could be 1) a combination of parental leave with a wage replacement benefit (in line with the Swedish model of parent insurance) and 2) a combination of family-related part-time work with wage-related, collectively financed subsidies (e.g. Mayer 2002: 213-215). As far as Germany is concerned, the financial means to pay for these schemes could come from restructuring the existing system of joint taxation of spouses, and the existing partial retirement scheme could serve as an organisational model ${ }^{6}$.

What is needed is a public debate as to which types of employment interruption or limitation should be subsidised (and which ones should not or no longer be subsidised) by society as a whole. If we take a closer look at the distribution of work, time and money over individual lifetimes, there are good arguments for organising collective support measures in such a way that they provide assistance when people are in the greatest need of time - in middle age when children have to be provided for. The findings of many employment biography studies support the idea that the promotion of reduced working hours (e.g. part-time work) and combinations of activities (e.g. in the form of 'parental part-time employment') is clearly preferable to the further extension of employment interruptions (e.g. through long parental leaves) with regard to subsequent employment prospects and income opportunities when the 'parenting phase' is over (Schwarze 2002).

One of the most urgent tasks in restructuring social welfare systems in line with the new needs of flexible and discontinuous life courses is to create broader access to the insurance and social security systems. This is especially the case in continental welfare states such as that of Germany where social insurance systems until today have been selective and geared towards the needs of dependent employees. In order to cushion the risks of flexibility and transitions, access would have to be opened for all those in gainful employment or even to all citizens (keywords: reorganisation of social insurance systems to create insurance systems for employed people/all citizens). To adjust to varying income from work over the lifetime people could obtain permission to 'buy' extra personal claims on a voluntary basis in times of high income, additional to their compulsory contributions to social insurance. This again would be the 'privatised' version to deal with flexibility over the lifetime and will come to its limits when people - due to short or discontinuous working biographies and low lifetime income - are not able or willing to

6 The German system of joint taxation of spouses is confined to married couples and in total provides about $€ 30 \mathrm{bn}$ per year for this group, irrespective of care responsibilities (Deutscher Bundestag 2002: 257-260). 
acquire sufficient claims for old age pensions. To solve this problem, a twofold strategy seems to make sense: 1) Instead of redistributing 'at the end of the working career', when pension claims turn out to be insufficient - either through the pension system or social assistance schemes - priority should be given to identifying the reasons why people fail to build up claims, and to finding solutions for the coverage of 'missing' periods and low income when the problem occurs (Vielle 2001; Vielle and Walthery 2003). This could be done by covering certain periods (such as care periods) by collective financing (via taxes or contributions), or by introducing new obligations for covering periods by individual contributions (e.g. payments of husbands for non-working wives, as in the Swiss system). The goal must be that every citizen builds up individual pension claims during working life that at least reach the level of the sociocultural minimum (e.g. social assistance). This approach takes into account the general preference for reciprocity as opposed to sheer redistribution. 2) To make this goal feasible, however, elements of minimum security and redistribution have to be strengthened within the public firstpillar pension systems. This refers in particular to insurance systems with a strong orientation towards equivalence between lifetime contributions and the later pension claim. The goal is not to abolish the correspondence between contributions and claims, but to weaken the principle of equivalence in favour of people with 'weak' earning and insurance biographies.

Broadening the obligation to build up one's pension claims and strengthening redistributive elements in the public systems could not only help to prevent poverty among people in flexible employment relationships and/or with discontinuous employment histories (both during employment phases and in retirement), but could also increase the awareness of employment risks.

As has been shown, a 'flexicurity over the life-course' model - which represents not so much a self-contained concept as a potential approach - comprises many areas for investigation and action that still need to be addressed.

\section{References}

Bauer, F., H. Groß, E. Munz and S. Sayin (2002) Arbeits- und Betriebszeiten 2001, Köln. Beblo, M. and E. Wolf (2002) 'How much does a year off cost? Estimating the Wage Effects of Employment Breaks and Part-Time Periods', Cahiers Économiques de Bruxelles 45 (2), 191-217.

Braun, Th. (2002) 'Flexibilität und soziale Sicherung in Dänemark unter besonderer Berücksichtigung von aktiver Arbeitsmarktpolitik und Weiterbildung', in U. Klammer and K. Tillmann (eds.) Flexicurity - Soziale Sicherung und Flexibilisierung der Arbeits- und Lebensverhältnisse, Düsseldorf, 637-680.

Cebulla, A. (2002) 'Flexibilität und soziale Sicherung in Großbritannien unter besonderer Berücksichtigung des 'New Deal', in U. Klammer and K. Tillmann (eds.) Flexicurity - Soziale Sicherung und Flexibilisierung der Arbeits- und Lebensverhältnisse, Düsseldorf, 585-636. 
Council of the European Union (2003) Council Decision of 22 July 2003 on guidelines for the employment policies of the Member States, OJ L 197, 5.8.2003, p.13.

De Witte, H. et al. (2002) 'Is temporary work a problem? Analysis of its consequences in Belgium, the Netherlands, Italy and Sweden', in M. Swerke et al. (eds.) European unions in the wake of flexible production, Papers presented at the Tenth European Congress on Work and Organizational Psychology in Prague 2001, National Institute for Working Life, Report No 6: 2002, Stockholm, 13-49.

Deutscher Bundestag (2002) Bericht der Bundesregierung zur Berufs- und Einkommenssituation von Frauen und Männern, Bundestags-Drucksache 14/8952, Berlin.

Erlinghagen, K. and M. Knuth (2002) Kein Turbo-Arbeitsmarkt in Sicht. Fluktuation stagniert - Beschäftigungsstabilität nimmt zu, IAT-Report 2002-04, Gelsenkirchen.

Esping-Andersen, G. (1990) The three worlds of welfare capitalism, Cambridge.

European Commission (2003) Employment in Europe 2003. Recent Trends and Prospects, Luxembourg.

European Foundation for the Improvement of Living and Working Conditions (ed.) (2003) A new organisation of time over working life, Luxembourg.

Gautié, J. (2003) 'Transitions et trajectories sur le marché du travail en France : mutations et conséquences', Troisièmes entretiens de l'emploi, ANPE, Mars.

Hertie-Stiftung (2003) Strategien einer familienbewussten Unternehmenspolitik. Berichtsband, Eine Untersuchung im Auftrag der Hertie-Stiftung, Bonn.

Hochschild, A. R. (2002) Keine Zeit. Wenn die Firma zum Zuhause wird und zu Hause nur Arbeit wartet, Opladen.

Jacobs, R. (2002) 'Integrated policy initiatives and integrated development models for the organisation of time over the life course', presentation at the workshop 'New organisation of time over Working Life', European Foundation for the Improvement of Working and Living Conditions, 14-15.11.2002, Brussels.

Keller, B. and H. Seifert (2002) 'Flexicurity - Wie lassen sich Flexibilität und soziale Sicherheit vereinbaren?' Mitteilungen aus der Arbeitsmarkt- und Berufsforschung 1/2002, 90-106.

Klammer, U. (2000) 'Auf dem Weg zu mehr Flexicurity in Europa', WSI-Mitteilungen 5/2000, 313-321.

Klammer, U. and K. Tillmann (2002) Flexicurity - Soziale Sicherung und Flexibilisierung der Arbeits- und Lebensverhältnisse, Forschungsprojekt im Auftrag des Ministeriums für Arbeit und Soziales, Qualifikation und Technologie des Landes NordrheinWestfalen, MASQT 1106, Düsseldorf.

Klenner, C., S. Pfahl and S. Reuyß (2003) 'Flexible Arbeitszeiten aus der Sicht von Eltern und Kindern' [Flexible Working Times Seen by Parents and Children], ZSE Heft 3, 268-285.

Lødemel, I. and H. Trickey (eds.) (2001) An offer you can't refuse: Workfare in international perspective, Bristol.

Madsen, P. K. (2003) 'Flexicurity through labour market policies and institutions in Denmark', in P. Auer and S. Cazes (eds.) Employment stability in an age of flexibility. Evidence from industrialized countries, ILO, Geneva.

Mayer, S. (2002) Deutschland armes Kinderland. Plädoyer für eine neue Familienkultur, Frankfurt a.M. 
OECD (1997) Employment Outlook 1997, Paris.

Pearce, J. (1998) 'Job insecurity is important, but not for the reason you might think: the example of contingent workers', in C. L. Cooper and D. M. Rousseau (eds.) Trends in Organizational Behavior, New York, 31-46.

Plantenga, J. and I. Koopmans (2002) 'Freistellungsregelungen für Sorgearbeit und ihre praktische Bedeutung im internationalen Vergleich', WSI-Mitteilungen 3, 161-168.

Prognos AG (2003) Betriebswirtschaftliche Effekte familienfreundlicher Maßnahmen Kosten-Nutzen-Analyse, Im Auftrag des Bundesministeriums für Familie, Senioren, Frauen und Jugend, Köln.

Rabe, B. and G. Schmid (1999) 'Eine Frage der Balance: Reform der Arbeitsmarktpolitik', Aus Politik und Zeitgeschichte, Beilage zur Wochenzeitschrift Das Parlament, B 37/1999, 21-30.

Rabe, B. and G. Schmid (2000) 'Strategie der Befähigung: Zur Weiterentwicklung der Arbeitsmarkt- und Rentenpolitik, WSI-Mitteilungen 5/2000, 305-313.

Schmid, G. (2000) 'Flexibilität und Sicherheit im globalen Sozialstaat', Gewerkschaftliche Monatshefte 8-9/2000, 497-507.

Schmid, G. and B. Gazier (eds.) (2002) The Dynamics of Full Employment. Social Integration Through Transitional Labour Markets, Cheltenham: Edward Elgar.

Schwarze, J. (2002) 'Auswirkung von Diskontinuitäten und 'atypischer' Beschäftigung in der Erwerbsbiografie auf das individuelle Erwerbseinkommen: Theoretische Analysen und Befunde empirischer Studien für Deutschland', in U. Klammer and K. Tillmann (eds.) Flexicurity - Soziale Sicherung und Flexibilisierung der Arbeits- und Lebensverhältnisse, Düsseldorf, 271-303.

Stuurgroep Verkenning Levensloop (2002) Verkenning Levensloop, The Hague.

Supiot, A. (1999) Au-delà de l'emploi, Paris.

Van Berkel, R. and I. Hornemann Møller (eds.) (2002) Active Social Policies in the EU. Inclusion through participation?, Bristol.

Vielle, P. (2001) La sécurité sociale et le coût indirect des responsabilités familiales, Bruxelles.

Vielle, P. and P. Walthéry (2003) Flexibility and social protection, European Foundation for the Improvement of Living and Working Conditions, Dublin.

Voß, G. and H. J. Pongratz (1998) 'Der Arbeitskraftunternehmer. Eine neue Grundform der Ware Arbeitskraft?' Kölner Zeitschrift für Soziologie und Sozialpsychologie, (1), 131-158.

Walker, R., D. Goodwin and E. Cornwell (2000) 'Work Patterns in Europe and Related Social Security Issues: Coping with the Myth of Flexibility', in D. Pieters (ed.) Changing Work Patterns and Social Security, EISS Yearbook 1999, London/The Hague/Boston, 5-43.

Wilthagen, T. (2001) 'Flexicurity': the Emergence of a New Paradigm in Labour Market and Employment Regulation? - the Dutch Background and Experiences', Paper presented at the 13th Annual Meeting on Socio-Economics, Amsterdam, 28 June to 1 July 2001. 